\title{
Theoretical and methodological fundamentals of pedagogical mastery according to Ivan Zyazyun
}

\author{
S. D. Isaieva \\ Taras Shevchenko National University of Kyiv, Ukraine \\ Corresponding author. E-mail: lana.dm.isv@gmail.com \\ Paper received 20.10.18; Revised 24.10.18; Accepted for publication 25.10.18.
} https://doi.org/10.31174/SEND-PP2018-181VI75-06

\begin{abstract}
The key role of the teacher in the modern globalized and computerized society is mentioned. Particular attention is paid to pedagogical interaction - the subject of Ivan Zyazyun's study. The essence of pedagogical mastery and the content of professional competence are revealed. The importance of teacher's communicativeness is noted. The significance of mastery of teacher's professional speech is emphasized. The expediency of pedagogical tact is considered. The importance of the ability of teachers to prevent conflict situations is underlined.

Keywords: Ivan Zyazyun, pedagogical mastery, interaction, humanistic approach, communicativeness, professional competence.
\end{abstract}

Introduction. Modern global integration processes can not bypass such important areas of social production as education and science. Today, there is not any doubts that the status and prospects of education and science are determinants of societal progress. They have become the basis of the productivity of societal manufacturing and determine the place of peoples and states not only in modern, but also in the future world [8].

The status of education in the modern world differs from that which existed in ancient times and even in the last millennium. Today's world has become too informative. This could not but affect the quality of modern education. Our education today is imperfect, it has been divided: on the one hand, it is a constant stream of information that has absorbed both students and teachers; on the other hand, it is the lack of a system of education aimed at the formation of young people's spirituality [9].

Taking into consideration the current situation, teachers should seek more effective teaching methods and means. A modern educational institution needs a teacher who understands a professional mission, perceives teaching activity as an important priority, and is a person capable of constant retraining and renovation [9].

Current approaches to solve existing problems of education in Ukraine put forward new requirements for teachers training, whose professional activity is determined by their professional, personal and communication skills. Thanks to the continuous search for ways of improving the educational process, the researches of scientists become more and more important [5, p.19].

Short review of the publications on the subject. The analysis of psychological and pedagogical literature testifies to the continuous scientific search for solutions to this problem, and is clearly elucidated in the works of such Ukrainian scholars as I. Zyazyun, V. Zhukovsky, V. Kan-Kalyk, O. Kozlova, M. Lazarev, M. Leshchenko, L. Milto, B. Mityurova, N. Nychkalo, S. Sysoieva, and others [6,4]. However, now we are focusing on the scientific position of the prominent Ukrainian scientist, doctor of philosophical sciences, professor, founder of the national school of pedagogical mastery Ivan Zyazyun. It should be noted that Ivan Zyazyun is the author of over 350 scientific works, including textbooks, tutorials and teaching aids, monographs on problems of pedagogical mastery, continuous professional education, ethics and aesthetics, the theory of Ukrainian and foreign culture, particularly: "Fundamentals of pedagogical mastery" (1987, 1989); "Pedagogical mastery" (1997); "The beauty of pedagogical activity" (1998); "Continuous profes- sional education: problems, searches, perspectives" (2000); "Pedagogy of goodness" (2000).

Thus, the purpose of the article is to examine theoretical and methodological fundamentals of pedagogical mastery of an educator from Ivan Zyazyun's viewpoint.

$\circ$ Presenting main material. Let's start with the fact that Ivan Zyazyun always emphasized the key role of the teacher in the development of civilizational processes from ancient times to modernity. Indeed, the profession of educator acquires a special status in a modern, globalized and informative society, which, beside the material and technological benefits, has hidden threats and risks in the context of the unification of processes of vital activity, that leads to a leveling of human individuality, produces stresses. Neutralization of the negative factors of influence on educational processes depends to a great extent on the educator, and this "requires the expansion of the teacher's functions, updating the content and forms of organization of its preparation in higher educational institutions of different levels of accreditation, in institutes of postgraduate education. The professional development of the teachers, their self-improvement, the level of pedagogical mastery takes on immense importance" [7, p.5].

Evaluating the achievements of a scientific school of pedagogical mastery, Ivan Zyazyun noted that the conception of pedagogical skill is based on the tradition of a humanistic approach in the world of pedagogy. The publication of the textbook and the chrestomathy "Pedagogical mastery" edited by I.A. Zyazyun - a scientific and methodical complex on problems of creative activity of the teacher, became a particularly valuable result of scientific researches of scientists and had an important scientific and practical significance not only for the Ukrainian but also for the world educational space, which is confirmed by the reissue of the textbook "Pedagogical mastery" in 2005 in Poland [7, p.7].

The subject of Ivan Zyazyun's study was pedagogical interaction. The scientist focused on the teacher's personality, his creative activity. He accentuated that the essence of pedagogical mastery is determined by the personality of the teacher, his humane and tolerant attitude to the student, the ability to creativity, professional activity, that manifests itself in specific situations of pedagogical interaction.

According to Ivan Zyazyun, pedagogical mastery is a "complex of personality's traits that provides selforganization of a high level of professional activity on a reflexive basis. Such important properties include the humanistic orientation of the teacher's activity, his professional competence, pedagogical abilities and pedagogical technique" $[7, \mathrm{p} .25]$. 
Ivan Zyazyun created the ideal image of pedagogical interaction, which should have become an example for imitation. Thus, from Ivan Zyazyun's point of view, pedagogical interaction is realized in various forms (a lesson, an educative teach-in, parents' meeting) and is a "set of pedagogical situations, that is, separate and simultaneously interrelated fragments of pedagogical activity, each of which contains all its features: there are certain contradictions between the actual state of education, the learning capabilities of students and the purpose for which the children's activities are organized; there are tasks which should be solved on the way to the goal; there are means with the help of which the teacher influences children. The way to achieve the educational goal can be imagined as the teacher and students' climbing up the staircase, embodying the program of gaining knowledge, spiritual growth" [7, p.20].

Referring to Ivan Zyazyun's opinion, "the basis of pedagogical mastery is professional competence. Knowledge and attainments of the teachers are addressed, on the one hand, to the subject they teach, and on the other hand - to students whose psychology the teachers must know well. Therefore, the content of professional competence means the knowledge of the subject, the methods of teaching it, pedagogy and psychology" [7, p.27].

What determines the scientific position of Ivan Zyazyun is that pedagogical activity should be engaged by the people with appropriate abilities that "depend on the peculiarities of the course of mental processes" [7, p.28] and that are manifested in communicativeness, empathy, acceptance, emotional stability and creativity.

Ivan Zyazyun defined communicativeness as "the professional and personal quality of an educator which is characterized as the need for communication, the ability to get in touch easily, to cause the positive emotions of interlocutors, to feel pleasure from communication" [7, p.104]. The signs of the communicative nature of the educator include the endeavor to interact with children, their parents, colleagues; the lack of an irritable negative reaction to the behavior of pupils; a sense of satisfaction from communication with students.

According to Ivan Zyazyun' position, only communicatively capable students can learn pedagogical techniques the form of the teacher's behavior which is "the ability to use the psychophysical apparatus as an instrument of educative influence, methods of self-possession (by controlling the organism, mood, speech, attention and imagination) and methods of influence on others (verbal and non-verbal means)" [7, p.29]. In accordance with the program "Teacher" developed by Ivan Zyazyun, it is necessary to implement the selection of matriculants to pedagogical institutions in order to determine the level of formation of communicative abilities.

Ivan Zyazyun also paid special attention to the teacher's speech - "an instrument of professional activity of the educator, with the help of which it is possible to solve various pedagogical tasks: to make the complex subject of the lesson interesting, and the process of studying attractive; to create a sincere atmosphere of communication in class, to establish contact with students, to reach an understanding with them; to form students' sense of emotional security, to instill them the belief in themselves" [7, p.48].

The course of pedagogical mastery is aimed specifically at the development of a teacher's speech as an instrument of pedagogical activity and is considered to be a communica- tive factor. According to Ivan Zyazyun, the teacher, who knows how to speak fluently, confidently and masterfully, can successfully implement the following functions: "a) a communicative function (establishment and regulation of relations between teachers and students, ensuring the humanistic orientation of students' development); b) a psychological function (creation of conditions for ensuring the psychological freedom of the students, the manifestation of individual identity of their personality, the removal of social clamps that interfere with this); c) a cognitive function (ensuring full perception of educational information by students, forming their personal, emotional and value attitude to knowledge); d) an organizational function (providing an efficient organization of educational and practical activity of students)" [7, p.50].

As for the view of Ivan Zyazyun, the teacher's speech acts as the regulator of relations "teacher-students", "largely determines pedagogical success or failure ... acts as a means of achieving the highest result of their development - mutual understanding between teachers and their pupils" [7, p.50]. In Ivan Zyazyun's pedagogical system just speech itself helps the teacher to implement the principles of goodness, partnership, cooperation and co-creation. Mastery of the teacher's professional speech was determined by Ivan Zyazyun as the "verbal action" on the students, the ability to stimulate dialogue with the teacher, "to create an atmosphere of joint thoughts and empathy" [7, p.54-55].

Mastering the ingenuity of pedagogical communication, as it was duly emphasized by Ivan Zyazyun, requires teachers' special training, which includes teaching them dialogue, the use of styles of pedagogical communication, ways of overcoming conflicts during pedagogical interaction [7, p.91], establishing relationships with pupils, parents, colleagues in different spheres of the educational process.

Considering the main types of monologue and dialogical pedagogic communication on the basis of the polarization of activities (in the monologue: some people instruct, command, dictate, others - passively perceive this influence, in the dialogue: active are all who participate in constructive cooperation), it is characteristic that Ivan Zyazyun's attention was focused on pedagogical dialogue - purposeful action in the pedagogical process, "which gives each partner the opportunity to express themselves in communication" [7, p.94].

As Ivan Zyazyun noted, in modern conditions the alteration in the minds of educators is fundamentally related to mastering their skill in conducting a dialogue. Under development of specific technologies of education humanization, attention is focused not on the content of education (albeit it is substantially), but on the formation of interpersonal relationships that provide comfortable conditions for the development of each child [2, p.55]. Speaking about mutual emotional influence during communication, Ivan Zyazyun introduced the notion of communicative interdependence between educators and pupils, that means a significant influence on creative well-being of the teacher and audience [2, p.108].

To determine the success of the dialogue as a criterion, Ivan Zyazyun offered to diagnose the quality of contact in a pedagogical dialogue, which is characterized by mutual understanding, empathy and willingness of teachers and students to interact. The presence of contact in the process of communication is indicated by mutual personal acceptance, openness in relationships, sincerity in statements; preservation of interest in further interaction; contact of eyes in the 
conversation; coherency of gestures and intonation in the dialogue [7, p.96].

According to the nature of the strategy of interaction, Ivan Zyazyun determined such communication styles: authoritarian (the style of dictate, when the inferior is considered only as a dormant doer without independence and initiative), democratic (the style which is based on deep respect to each person), liberal (the style that is characterized by the lack of a stable pedagogical position and is manifested in noninterference, the formal solution of problems) [7, p.100].

Considering the essence, structure and technology of constructing professional pedagogical communication, Ivan Zyazyun determined the possibility of emerging conflict situations when the relations between teachers and students are complicated [7, p.102].

Ivan Zyazyun recommended to develop the educators' ability to balanced actions to prevent the emergence of a conflict situation. He believed that recklessness in a conflict situation could lead to the accumulation of passions, uncontrolled behavior, open confrontation and the desire to break the relationship. Then the conflict arises, after which hard and great work on the revival of business relations takes place. Although Ivan Zyazyun did not provide rigid recommendations concerning resolving conflicts, he emphasized that each conflict in pedagogical practice is an acute situation, which, however, due to increased emotionality, can promote awareness of moral laws. So, "it is important to look at the conflict as at a spontaneously emerged or specially created contradictions in the relations between teachers and students, which, on condition a constructive decision, leads to positive changes in the relations of its participants, their development and development of the whole collective. Teachers should not be afraid of conflict. If it arises, they must master the technology of behavior in a conflict situation" [7, p.103].

As a supporter of the prevention of acute conflict situations, Ivan Zyazyun considered it expedient to define fully the pedagogical tact, which is based on tolerance, teacher's empathy. From his point of view, in a pedagogical process, the teacher must try to encourage children to dialogue in order to help them learn to organize creatively the activity and construct the relations [7, p.103].

Conclusions and prospects for further scientific research. Thus, the course of pedagogical mastery is practically oriented and aimed at preparing teachers for the art of pedagogical action, the central task of which is the students' mastering the skills of effective professional communication. Ivan Zyazyun analyzed the methods and techniques used by the teacher in the interaction, herewith operating the communication style category. At the same time, he defined democratic communication as the most desirable in comparison with the authoritarian and liberal ones.

If we consider the algorithmic sequence of development of ideas of pedagogical mastery, then it has such format: philosophy - pedagogy - pedagogical mastery, that is, the conceptual fundamentals of pedagogical skill were philosophy and pedagogy, and in recent years the ideas of humanistic psychology have organically joined to them.

\section{ЛІТЕРАТУРА}

1. Зязюн I. Наука і мистецтво педагогічної дії / I. Зязюн // Професійна освіта: педагогіка і психологія. - Київ. - 2001. Випуск 3. - С. 357-380

2. Зязюн I. Краса педагогічної дії / I. Зязюн // Навчальний посібник. - Київ. $-1997 .-302$ c.

3. Зязюн І. Філософія педагогічної дії / І. Зязюн // Монографія. Черкаси. -2008. -608 c.

4. Ісаєва С. Характерні особливості реалізації системи підготовки викладачів до ефективної педагогічної взаємодії зі студентами / С. Ісаєва // Імідж сучасного педагога. - 2016. №7 (166). - C.26-29

5. Isaieva $\mathrm{S}$. The role of pedagogical strategies of effective communication in the process of teachers interaction with students / S Isaieva // Science and Education a New Dimension: Pedagogy and Psychology. - V. (51), Issue: 112. - Budapest, Hungary. -

6. Лещенко М. Щастя дитини - єдине дійсне щастя на землі: до проблеми педагогічної майстерності / М. Лещенко // Навчально-методичний посібник. - Київ. - 2003. - Ч.1. - 304 с.

7. Педагогічна майстерність / I. Зязюн [та ін.]; за редакцією I. Зязюна // Підручник. - Київ. - 2008. - 462 с.

8. Олексик Х., Данканич О. Проблеми гармонізації національних традицій та інновацій в навчально-науковому процесі BН3 / Х. Олексик, О. Данканич // Інновації в навчальному процесі вищих навчальних закладів: міжнародний та національний досвід. - Ужгород, Україна; Сніна, Словаччина. 2008. - С.255-260

9. Остапенко О. Упровадження інноваційних форм навчання складова успіху і педагогічної майстерності викладача / О. Остапенко // Освіта, технікуми, коледжі. - №1 (22). - 2009. C.16-18

\section{REFERENCES}

1. Zyazyun I. Science and art of pedagogical action / I. Zyazyun // Professional education: pedagogy and psychology. - Kyiv. 2001. - Issue 3. - P. 357-380

2. Zyazyun I. Beauty of pedagogical action / I. Zyazyun / / Textbook. - Kyiv. -1997 . $-302 \mathrm{p}$.

3. Zyazyun I. Philosophy of Pedagogical Action / I. Zyazyun // Monograph. - Cherkasy. -2008 . -608 p.

4. Isaieva S. Characteristic features of the implementation of the teacher training system for effective pedagogical interaction with students / S. Isaieva // Image of modern educator. - 2016. - № 7 (166). - P. 26-29

5. Isaieva S. The role of pedagogical strategies of effective communication in the process of teacher interaction with students / S Isaieva // Science and Education a New Dimension: Pedagogy and Psychology. - V. (51), Issue 112. - Budapest, Hungary. 2017. - P.19-21

6. Leshchenko M. Happiness of the child is the only true happiness on the Earth: to the problem of pedagogical mastery / M. Leshchenko / Educational and methodical manual. - Kyiv. - 2003. Part 1. -304 p.

7. Pedagogical Mastery / I. Zyazyun [and others]; edited by I. Zyazyun // Textbook. - Kyiv. - 2008. - 462 p.

8. Oleksyk H., Dankanych O. Problems of harmonization of national traditions and innovations in the educational and scientific process of higher education institutions / H. Oleksyk, O. Dankanych // Innovations in the educational process of high schools: international and national experience. - Uzhgorod, Ukraine; Snina, Slovakia. - 2008. - P. 255-260.

9. Ostapenko O. Implementation of innovative forms of education a component of the success and teacher's pedagogical mastery / O. Ostapenko // Education, technical schools, colleges. - № 1 (22). - 2009. - P.16-18 